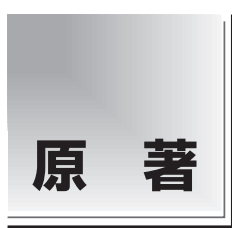

論文受付 2016 年 2 月 7 日

論文受理 2016 年 7 月 28 日

Code Nos. 1000 1090

\section{北海道における放射線診療資源の地理的分布の経年比較 一ジニ係数とハーフィンダール・ハーシュマン指数 を用いた分析一}

藤原健祐 ${ }^{1}$ 谷川原綾子 ${ }^{2}$ 谷川玩海 ${ }^{3}$ 谷 祐児 $^{4}$ 大場久照 ${ }^{2}$ 小笠原克彦 ${ }^{5}$

\author{
${ }^{1}$ 北海道大学大学院保健科学院 \\ 2 北海道科学大学保健医療学部 \\ 3 旭川医科大学病院 経営企画部 (現 北海道科学大学保健医療学部) \\ ${ }^{4}$ 北海道大学大学院保健科学研究院(現 旭川医科大学病院経営企画部) \\ ${ }^{5}$ 北海道大学大学院保健科学研究院
}

\section{緒 言}

近年, 画像診断機器, 放射線治療機器の技術革新の 進展により日本では多くの医療施設において多種多様 な放射線診療機器が導入されている。“OECD Health
Data 2012”によると, 2005 年の日本における放射線 治療機器台数は人口 100 万人あたり 6.8 台であり他の OECD 加盟国と比較して多くはないものの，2008 年 の computed tomography $(\mathrm{CT})$, magnetic resonance

\title{
Trends for the Geographic Distribution of Radiological Resources in Hokkaido, Japan: Data Analysis Using Gini Coefficient and Herfindahl-Hirschman Index
}

\author{
Kensuke Fujiwara, ${ }^{1}$ Ayako Yagahara, ${ }^{2}$ Takumi Tanikawa, ${ }^{3}$ Yuji Tani, ${ }^{4}$ Hisateru Ohba, ${ }^{2}$ \\ and Katsuhiko Ogasawara ${ }^{5 *}$ \\ ${ }^{1}$ Graduate School of Health Sciences, Hokkaido University \\ ${ }^{2}$ Faculty of Health Sciences, Hokkaido University of Science \\ ${ }^{3}$ Department of Medical Informatics and Hospital Management, Asahikawa Medical University Hospital (Current address: \\ Faculty of Health Sciences, Hokkaido University of Science) \\ ${ }^{4}$ Faculty of Health Sciences, Hokkaido University (Current address: Department of Medical Informatics and Hospital \\ Management, Asahikawa Medical University Hospital) \\ ${ }^{5}$ Faculty of Health Sciences, Hokkaido University
}

Received February 7, 2016; Revision accepted July 28, 2016

Code Nos. 1000,1090

\section{Summary}

The aim of this study is to analyze the maldistribution and the trends in the geographic distribution of radiological resources in secondary medical areas of Hokkaido. The distribution was measured by combining the Gini coefficient (GC), which is an indicator of inequality of distribution, and the Herfindahl-Hirschman index (HHI) , which is mainly used to assess market concentration. Data concerning the distribution of radiological resources, such as CT, MRI, radiotherapy facilities (RTF), radiological technologists (RT), and medical doctors were obtained from official publications. CT was more equally distributed, and RTF was more inequality than other radiological resources in 2014. Radiological resources excluded CT were higher degree of concentration than population distribution, and it showed that they were located relatively more intensively in urban areas than in rural areas. During the period 1999-2014, the GC for CT, MRI, RTF, and RT decreased, while the HHI increased. These trends indicated increased equality of distribution of CT, MRI, RTF, and RT and the concentration in urban areas. This study suggested that GC and HHI could be powerful indicators for allocation planning of medical resources with further analysis of the maldistribution of medical resources.

Key words: radiological resources, geographic distribution, inequality, concentration, trend 
imaging (MRI) 台数は人口 100 万人あたりそれぞれ 97.3 台, 43.1 台であり, OECD 加盟国の平均值 22.6 台, 12.5 台を大きく上回っている ${ }^{1)}$.しかし, これらの 放射線診療機器の分布は地理的に均一ではなく, 人口 の多い都市部にはより多くの機器が分布しており，一 方で人口減少や高齢化の進む地方ではより少ない傾向 にある。そのため, へき地医療拠点病院からは医療提 供体制に関する機能として CT や MRIのような高度 医療機器が必要であることや ${ }^{2}$, 都市部と地方での医 療資源の偏在による診療格差があることが指摘されて いる3 ${ }^{3,4)}$.

北海道は日本の国土全体の $22 \%$ の面積を有してい るにもかかわらず, 人口の多くは札幌や旭川などの一 部の都市とその付近に集中している, 北海道では以前 から医療資源の偏在が指摘されており，2008 年の第 5 次北海道医療計画に扔いて人口減少 ·高齢化の急速な 進行や都市部への集中などを背景に，良質かつ適切な 医療を効率的・継続的に提供する体制を確立するとし ていた5)。医療計画では地域の医療需要に対応して医 療資源の適正な配置と医療提供体制の整備を図るため の地域的な単位として医療圈を定義しており，このう ち二次医療圈は「一般の入院に係る医療を提供するこ とが相当である単位 (三次医療圈で提供すべき医療を 除く.)」(厚生労働省など) とされ, 地理的条件等の自 然的条件抒よび日常生活の需要の充足状況, 交通事情 等の社会的条件を考慮して設定されている，また，直 近の第 6 次医療計画に拈いては, 新たに医療計画の実 効性を高めるために plan-do-check-act (PDCA)サイ クルの推進が求められるようになった ${ }^{6)}$. 医療計画で 定めた二次医療圈という地域単位において自然的条件 および社会的条件を考慮した医療資源の適正な配置に 向けて，医療資源の偏在を評価し，是正を行っていく ことが喫緊の課題となっている.

日本の医療提供体制では, 公的医療保険による国民 皆保険制度のもと, 医療サービスという現物を給付す る方式での保険給付を行っており，患者になりうる国 民に対しては，医療を受ける機会を公平に提供するこ とが必要である。しかし, 市場メカニズムによる自由 競争では，公平性を担保することが困難であるため， 行政が保険医療制度に基づくさまざまな規制等を作 り，国民皆保険制度を維持している。一方，このよう な不完全な競争環境下に㧍いては資源分配が非効率的 になることから，一般に医療分野は「市場の失敗」に 該当するケースであることが知られている7 . 医療提 供体制が適切であるかを評価するためには，患者が医 療を受ける機会の公平性という観点から，医療資源の
分布を明らかにすることが重要であるといえる.

医療の公平性の評価基準として，二次医療圈が自然 的条件拉よび社会的条件という複合的な要素によって 設定されていることを考慮すれば，その圈域内に居住 する人口と医療資源数の関係から求められる二次医療 圈間の分布の均一性は, ひとつの重要な指標であると 考えられる。もし市場メカニズムが機能していれば, 経年的な人口の都市部への集中に伴って, 医療資源も 都市部へ集中するが，さまざまな規制の下では，人口 および資源分布は必ずしも医療の公平性を満たす均一 な分布を示さない可能性がある。

これまで，地域的な医療資源の適正配置問題につい ては医師偏在に関する多くの報告があり, 偏在の指標 のひとつとしてジニ係数 (Gini coefficient: GC)が用い られている ${ }^{8 \sim 10)}$ ＧC は社会に扮ける所得分配の不平 等さを測る経済指標であり，医療分野では対象地域の 医療資源数が人口に対してどの程度均一に分布してい るかを表す指標として応用されている，Ogasawara らは北海道に扔ける二次医療圈を単位とした放射線診 療の地域的な不均一性について GC を用いて評価して おり, 1996 年の北海道において放射線科医と放射線治 療機器の分布は不均一であり, CT や MRI などの画像 診断機器は均一に分布していたと報告している ${ }^{11)}$. 放 射線治療機器, 放射線科医, 診療放射線技師などの放 射線治療分野に着目した分布の評価は報告されている ものの ${ }^{12,13)}$ ，放射線診療資源，特にCT や MRI のよう な画像診断機器の分布を評価した研究は少なく, 近年 の状況や現在に至るまでの経年変化は明らかになって いない.

このように医療資源の偏在を評価したこれまでの先 行研究では，GCが多く用いられている。しかし，GC を用いた分布の不均一性の評価は，GC が人口あたり の資源数をもとに算出されるため, 調査対象年時点で の人口と資源数のバランスを評価することが可能であ るものの, 経年的な人口と資源数の変化を別々に評価 することはできない，そこで，本研究では，人口拉 び資源数の変化を個別に評価するための指標として市 場の集中度評価に使用されるハーフィンダール・ハー シュマン指数 (Herfindahl-Hirschman index: HHI)を追 加し, 変化要因を考慮した分析を GC と合わせて行う ことにした，小松らは新臨床研修制度の研修プログラ ムにおいて研修医が多くの疾患を経験できているかを 評価するために GC と HHI を併用して平準度の指標 としている ${ }^{14)}$.

本研究の目的は，住民の放射線診療資源へのアクセ シビリティの公平性の視点から北海道に抢ける放射線 
診療資源の偏在を検討する基礎資料とするため, GC と HHI を併用した新たな分析手法を用いて放射線診 療資源の分布の経年変化を明らかにすることである.

\section{1. 対象と方法}

\section{1-1 対 象}

病院および診療所について，その分布および整備の 実態を明らかにする目的で厚生労働省により 3 年ごと に実施される医療施設静態調査に合わせ，対象年次は 1999 年抢よび直近の 2014 年とした ${ }^{15)}$ ．放射線診療資 源は, 放射線診療機器としてCT, MRI, 放射線治療機 器 (radiotherapy facilities: RTF) を, 医療従事者として 放射線診療機器の操作・管理を行う診療放射線技師 (技師)を対象とした。また，GCの数值には目安は存 在するものの，どの程度であれば偏在しているといっ た基準は存在しないため相対的な評価になることか ら，比較対象として地域的な偏在が報告されている医 師を追加した ${ }^{8 \sim 10)}$. 本研究では住民の放射線診療資源 へのアクセシビリティの公平性の視点から評価するた め, 医師の GC を比較基準とし放射線診療資源の GC との大小から住民の感じる不平等度を推測した． CT の総数は, 1999 年および 2014 年の医療施設調查を用 いて分類されている項目に則り，1999年は「全身用X 線 CT」と「頭部(頭頸部) 用 X 線 CT」の病院および一 般診療所が保有する台数を合計し，2014 年は「マルチ スライス CT」と「その他の CT」の台数を合計した. 同様に MRI の総数について, 1999 年は「NMR-CT (MRI)」の台数を用い, 2014 年は「MRI3.0 T 以上」と $\lceil\mathrm{MRI1} .5 \mathrm{~T}$ 以上 $3.0 \mathrm{~T}$ 未満」と「MRI1.5 T 未満」の台 数を合計した，RTFの総数についても同様に, 各年 次の医療施設静態調査において分類表記されている機 器を対象とし, 1999 年は「リニアック・ベータトロ ン・マイクロトロン」の台数を用い, 2014 年は「リニ アック・マイクロトロン」と「ガンマナイフ・サイバー ナイフ」と「RALS」の台数を合計した。 なお，分類表 記されている機器を対象としているため両年で一部機 器が異なっている，診療放射線技師数は各年次とも病 院報告を用いて病院に勤務する「診療放射線技師」と 「診療エックス線技師」の常勤換算值を合計し，医療施 設調查を用いて一般診療所に従事する「診療放射線技 師」と「診療エックス線技師」の常勤換算值を合計し, その両方の合算值を使用した ${ }^{15,16)}$. 医師数も診療放射 線技師数と同様に, 病院報告㧍よび医療施設調査を用 いて病院および一般診療所に従事する医師の「常勤」 および「非常勤(常勤換算)」の合計である「総数」の合 算值を使用した。人口は各年次の住民基本台帳の市区

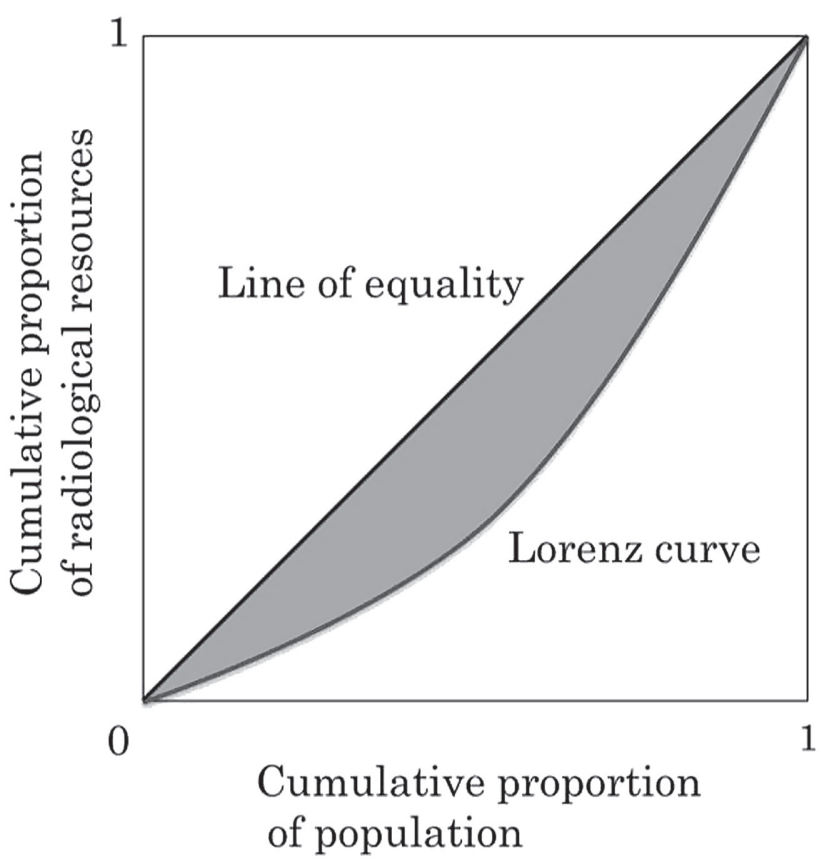

Fig. 1 The Lorenz curve and the Gini coefficient. The Lorenz curve is a measure of the distribution of wealth in a society. The horizontal axis represents the population cumulative proportion of target areas, and the vertical axis represents the cumulative proportion of radiological resources, such as CT or MRI. The Gini coefficient is calculated to double the area enclosed by the line of equality and the Lorenz curve.

町村別人口を用いた。すべての集計值は北海道の 21 の二次医療圈ごとに算出した.

1-2 ジニ係数とハーフィンダール・ハーシュマン指数

GC の算出のために，まず二次医療圈を放射線診療 資源数/人口比でランク付けし, 最低ランクから各圈 域の累積放射線診療資源数を縦軸, 累積人口を横軸と する座標平面上にプロットしたローレンッ曲線を描い $た^{10)}$ (Fig. 1).

GC は $(0,0)$ 点と $(1,1)$ 点とを結ぶ均等分布線とこの 曲線に囲まれた面積を 2 倍したものであり, 以下の式 から算出した ${ }^{12,13)}$.

$\mathrm{GC}=\left(\sum_{i=1}^{n-1} x_{i} \cdot y_{i-1}\right)-\left(\sum_{i=1}^{n-1} x_{i-1} \cdot y_{i}\right)$

$n$ は北海道の二次医療圈数であり, $x_{i}$ は二次医療圈 $i$ に扮ける人口の累積比率， $y_{i}$ は放射線診療資源の累 積比率である。GCは 0 から 1 の間を取り，1に近い ほどその分布が不均一であることを示す，実用的な不 均一度の評価基準として, 0.2 未満は「絶対的な均一」, 0.2 0.3 は「高い均一」, $0.3 \sim 0.4$ は「不均一」, $0.4 \sim 0.6$ は「高い不均一」, 0.6 以上は「絶対的な不均一」を表す とされている ${ }^{17)}$. 
Table 1 Population and number of radiological resources in Hokkaido in 1999

\begin{tabular}{rcrrrrrr}
\hline \hline$\#$ & Medical areas & Population & CT & MRI & RTF & MD & RT \\
\hline 1 & Minami Oshima & 443,039 & 42 & 13 & 3 & 888 & 147 \\
2 & Minami Hiyama & 33,055 & 6 & 1 & 0 & 54 & 12 \\
3 & Kita Hiyama-Oshima & 48,670 & 4 & 1 & 0 & 71 & 14 \\
4 & Sapporo & $2,205,711$ & 251 & 78 & 12 & 5,274 & 1,080 \\
5 & Shiribeshi & 267,877 & 33 & 7 & 0 & 568 & 93 \\
6 & Minami Sorachi & 208,233 & 20 & 5 & 2 & 367 & 76 \\
7 & Naka Sorachi & 141,242 & 20 & 8 & 1 & 265 & 56 \\
8 & Kita Sorachi & 42,346 & 4 & 1 & 0 & 88 & 13 \\
9 & Nishi Iburi & 218,977 & 23 & 6 & 2 & 486 & 96 \\
10 & Higashi Iburi & 221,279 & 22 & 6 & 1 & 340 & 70 \\
11 & Hidaka & 87,188 & 12 & 2 & 0 & 121 & 23 \\
12 & Kamikawa Cyubu & 421,752 & 52 & 18 & 4 & 1,171 & 180 \\
13 & Kamikawa Hokubu & 82,889 & 10 & 2 & 0 & 138 & 28 \\
14 & Furano & 49,962 & 7 & 2 & 0 & 75 & 16 \\
15 & Rumoi & 67,558 & 5 & 2 & 0 & 100 & 19 \\
16 & Soya & 82,906 & 10 & 2 & 0 & 102 & 25 \\
17 & Hokumou & 250,105 & 31 & 7 & 3 & 383 & 82 \\
18 & Enmon & 88,397 & 13 & 4 & 0 & 156 & 27 \\
19 & Tokachi & 362,036 & 42 & 12 & 1 & 517 & 125 \\
20 & Kushiro & 280,723 & 26 & 12 & 3 & 468 & 115 \\
21 & Nemuro & 87,792 & 9 & 2 & 0 & 85 & 21 \\
\hline & All over Hokkaido & $5,691,737$ & 642 & 191 & 32 & 11,716 & 2,318 \\
\hline & ovis
\end{tabular}

RTF: radiotherapy facilities, MD: medical doctors, RT: radiological technologists

次に，一般的な HHI の算出は個別事業者ごとに当 該事業者の事業分野占拠率を二乗した值を計算し，こ れを当該品目に係る全事業者について合計したものと して以下の式で算出される ${ }^{18)}$.

$\mathrm{HHI}=\sum_{i=1}^{n} S_{i}^{2}$

$n$ は企業数, $S_{i}$ は企業 $i$ の市場シェアである. 全事 業者数を $n$ とすると HHI は $1 / n$ から 1 の值をとり, 首位事業者の事業分野占拠率が高いほど大きな値とな り，首位事業者の事業分野占拠率が同じでも2 位以下 の事業者の事業分野占拠率が低いほど小さな值とな る. 本研究ではこの考え方を援用し，人口や放射線診 療資源の集中度を表す指標を以下の式から算出した。

$\mathrm{HHI}=\sum_{i=1}^{n}\left(\frac{z_{i}}{z_{t}}\right)^{2}$

$n$ は北海道の二次医療圈数であり, $z_{t}$ は北海道の人 口または放射線診療資源数, $z_{i}$ は二次医療圈 $i$ の人口 または放射線診療資源数である。一般的な HHI と同 様に $1 / n$ から 1 の間をとり，1に近いほどその分布が 特定の二次医療圈に集中していることを示す。一般的 な HHI は日本，アメリカ，EUのガイドラインで市場 の集中度を計る指標として導入されており，日本では 0.25 以上が市場集中の一つの目安とされている ${ }^{19}$.

\section{1-3 偏在の定義とその評価}

本研究では住民の放射線診療資源へのアクセシビリ ティの公平性の視点から, 二次医療圈を単位として人 口あたりの放射線診療資源数が等しくなることを偏在 のない均一な分布と仮定した。 この仮定のもとで, GC が 0 であること, かつ人口の HHI が放射線診療資 源の HHI と等しいことが均一分布となる。縦軸を GC，横軸を HHI として各年次のデータおよび均一分 布を示す(人口の HHI，0)点をプロットし，1999 年お よび 2014 年において放射線診療資源の分布が仮定し た均一分布であるかどうかを評価した。

\section{2. 結 果}

\section{2-1 集計結果}

1999 年, 2014 年における北海道の二次医療圈ごと に集計した人口拈よび放射線診療資源数を示す (Table 1, Table 2).

札幌市を含む二次医療圈「札幌」に全道人口の約 $40 \%$ が集中しており，1999 年から 2014 年において全 人口は減少しているが, 「札幌」のみ人口が増加し, 他 の圈域はすべて人口が減少していた。また，この期間 に放射線診療資源の総数はすべての項目で増加してお り, 特に MRI の増加が著しく, その総数は約 2.2 倍に 増加していた。 
Table 2 Population and number of radiological resources in Hokkaido in 2014

\begin{tabular}{rcrrrrrr}
\hline \hline$\#$ & Medical areas & Population & CT & MRI & RTF & MD & RT \\
\hline 1 & Minami Oshima & 397,895 & 53 & 33 & 6 & 925 & 202 \\
2 & Minami Hiyama & 25,673 & 5 & 2 & 0 & 40 & 11 \\
3 & Kita Hiyama-Oshima & 38,997 & 9 & 1 & 0 & 67 & 19 \\
4 & Sapporo & $2,356,575$ & 346 & 198 & 28 & 7,091 & 1,412 \\
5 & Shiribeshi & 223,732 & 48 & 18 & 1 & 484 & 97 \\
6 & Minami Sorachi & 173,549 & 28 & 11 & 1 & 313 & 75 \\
7 & Naka Sorachi & 113,818 & 22 & 8 & 1 & 276 & 72 \\
8 & Kita Sorachi & 34,177 & 4 & 1 & 0 & 67 & 14 \\
9 & Nishi Iburi & 195,263 & 30 & 14 & 1 & 469 & 122 \\
10 & Higashi Iburi & 215,841 & 30 & 12 & 2 & 392 & 91 \\
11 & Hidaka & 72,753 & 11 & 4 & 0 & 109 & 28 \\
12 & Kamikawa Cyubu & 404,957 & 70 & 42 & 8 & 1,309 & 231 \\
13 & Kamikawa Hokubu & 68,729 & 10 & 3 & 0 & 145 & 36 \\
14 & Furano & 44,442 & 6 & 3 & 0 & 78 & 14 \\
15 & Rumoi & 53,408 & 7 & 3 & 0 & 91 & 22 \\
16 & Soya & 66,975 & 12 & 4 & 0 & 92 & 23 \\
17 & Hokumou & 226,532 & 34 & 14 & 1 & 414 & 103 \\
18 & Enmon & 74,257 & 13 & 6 & 0 & 131 & 35 \\
19 & Tokachi & 350,442 & 59 & 23 & 3 & 684 & 172 \\
20 & Kushiro & 244,836 & 38 & 16 & 3 & 472 & 148 \\
21 & Nemuro & 80,194 & 9 & 4 & 0 & 87 & 24 \\
\hline & All over Hokkaido & $5,463,045$ & 844 & 420 & 55 & 13,737 & 2,950 \\
\hline
\end{tabular}

Table 3 The Gini coefficient of radiological equipment and medical staff in 1999 and 2014

\begin{tabular}{ccccc}
\hline \hline Category & Subcategory & 1999 & 2014 & Amount of change \\
\hline Radiological equipment & CT & 0.064 & 0.062 & -0.002 \\
& MRI & 0.110 & 0.095 & -0.015 \\
& RTF & 0.325 & 0.263 & -0.062 \\
Medical staff & MD & 0.118 & 0.125 & +0.007 \\
& RT & 0.104 & 0.078 & -0.026 \\
\hline
\end{tabular}

Table 4 The HHI of the population, radiological equipment, and medical staff in 1999 and 2014

\begin{tabular}{lcccc}
\hline \hline \multicolumn{1}{c}{ Category } & Subcategory & 1999 & 2014 & Amount of change \\
\hline Population & & 0.179 & 0.211 & +0.032 \\
Radiological equipment & CT & 0.181 & 0.196 & +0.015 \\
& MRI & 0.196 & 0.249 & +0.053 \\
& RTF & 0.193 & 0.301 & +0.108 \\
Medical staff & MD & 0.230 & 0.289 & +0.059 \\
& RT & 0.240 & 0.253 & +0.013 \\
\hline
\end{tabular}

2-2ジニ係数とハーフィンダール・ハーシュマン指 数の経年変化

1999 年に扔ける放射線診療資源の GC は，医師の 0.118 と比較して MRIの 0.110 と技師の 0.104 は同程 度, RTF の 0.325 は高值, CT の 0.064 は低值であり, RTF は不均一な分布, CT は均一な分布であった (Table 3).

1999 年から 2014 年における GC の医師およびCT の変化量は微小であり分布に大きな変化はみられない
ものの, MRI, RTF, 技師の GC は低下しており, 特に $\mathrm{RTF}$ はその度合いが大きく不均一分布の改善傾向が みられた。

人口の $\mathrm{HHI}$ は 1999 年の 0.179 から 2014 年の 0.211 へと上昇しており，人口分布の都市集中傾向がみられ た(Table 4).

同様に放射線診療資源の HHI はいずれも上昇して おり，都市への集中傾向がみられたが，2014 年におけ る CT の HHI のみが人口の HHI よりも低值であっ 


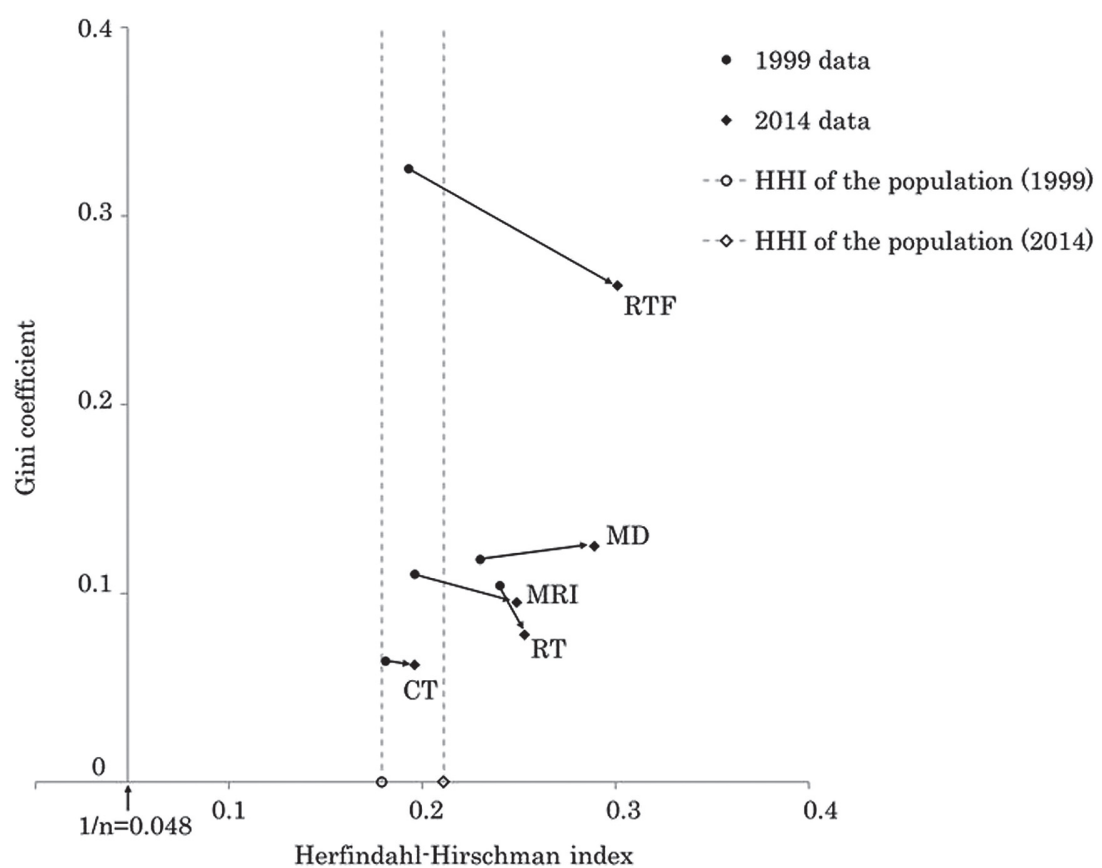

Fig. 2 Trends for the GC and the HHI during the period 1999-2014.

Filled symbols of circles and diamonds indicate the 1999 and 2014 data of radiological resources, respectively. Open symbols of a circle and a diamond are the coordinate (HHI of the population, 0 ) indicating optimum arrangement in 1999 and 2014, respectively. The arrowhead shows the direction of time-dependent change from 1999 to 2014.

た。いずれの年次においても医師の HHI は人口の HHI よりも高く, MRI, RTF，技師についても同様で あり，都市部へ集中した。

1999 年から 2014 年における放射線診療資源数の増 加を伴う経年変化について，仮定した均一分布となる ように配置がなされていたのは CTのみであった (Fig. 2).

医師のみ $\mathrm{GC}$ と $\mathrm{HHI}$ がともに上昇しており，CT, MRI，RTF，技師は GC が低下しているものの HHI が 上昇していた。

\section{3. 考 察}

本研究では 1999 年と 2014 年における北海道の二次 医療圈を単位とした放射線診療資源の分布を定量的に 評価し，GCの評価に抢いては，その分布の均一性を 医師の分布を基準にして比較した，HHIの評価にお いては，人口と放射線診療資源のそれぞれの分布を比 較し，人口の HHI よりも放射線診療資源の HHI が高 值であれば，人口以上に放射線診療資源が集中傾向に あり，特に 0.25 を超えた場合に集中傾向が顕著である とした。 2014 年において，CT 以外の放射線診療資源 の HHI は人口の HHI より高值であり, RTF, 医師, 技師の HHI は集中の目安とされる 0.25 を超えてい た。また，GCの比較対象とした医師は 1999 年と 2014 年を比較すると，GCと HHI がともに上昇して
いた，医師の総数は増加しているものの，都市部に集 中したことで不均一分布が顕著に現れたと予想され， このことは現在日本で問題となっている医師偏在を反 映していると考えられる ${ }^{20,21)}$.

2014 年において，RTF の GC および HHI は対象と した放射線診療資源の中で最大であった，RTFの GC を一般的な評価基準に照らし合わせると 1999 年は 「不均一」，2014 年は「高い均一」を示したが，医師と 比較するといずれの年も高值であり, HHI も 0.25 を 超えていたことから, RTFの分布は均一に近いもの の, 都市部への集中傾向が強いと考えられる. RTF は 2014 年時点において北海道の二次医療圈のうち 10 圈域で配置がなされていないが，放射線治療に関わる がん診療は最先端で高度な技術を提供する特殊な医療 を行う三次医療圈でカバーされており，がん診療連携 拠点病院が未指定となっている二次医療圈は 12 圈域 存在している ${ }^{22)}$. 本研究の結果はこの現状を反映して おり, 特定の二次医療圈にのみ配置されていることで HHI が高值となり，二次医療圈単位でみると他の放射 線診療資源と比較して不均一に分布していたと考えら れる。

一方，放射線診療資源の中で最も GC が低かったの は CT であり, 同様に HHI も人口の HHI に比べて低 かったことから，CTは地方にも十分に配置され均一 に分布していることが推測された。また，CTの総数 
は 1999 年と 2014 年で大きな変化はないことから, 北 海道における CT 導入状況は飽和しており，人口動態 や機器台数の大きな変化がなければ，この均一な分布 は保たれると考えられる。しかし，今後は地方の人口 減少が加速すると考えられており，人口あたりの機器 台数が過㮃になる可能性が示唆される.人口に対する 放射線診療資源の二次医療圈間の差が少しでも大きく なった場合，GCの值は不均一度が上昇するように必 ず変化するため, 継続的に経年変化を評価し, 不均一 度が高くなった場合は医療資源の集約を促す対策が必 要になると考えられる.

MRI の総数は 1999 年から 2014 年にかけて約 2.2 倍 に増加し, その増加率は放射線診療資源の中で最大で あった，他の放射線診療資源と比較すると，GCの変 化は小さいが，HHIが大きく上昇しており，このこと はMRIが地方にも配置されたが, 増加分の多くは都 市部が中心であることを示している，仮にこの傾向が 今後も続いた場合には, GC が上昇へと転じ, 医師と 同様に本研究で定義した均一分布から逸脱した不均一 な分布になる可能性があるため, CT と同様に継続的 な経年変化の評価が必要と考えられる，近年，CT や MRIのような画像診断機器が診療所にも多く配置さ れるようになっているが, 診療所は大病院がある一部 地域に集中して立地する傾向にあり ${ }^{23)}$ ，今後も画像診 断機器は都市部を中心に分布することが継続していく と予想される。また， CT， MRI， RTFのような放射 線診療機器を操作・管理する技師は, 放射線診療機器 の導入に伴って人員の拡充が行われることが多く, 1999 年と 2014 年の比較においても放射線診療機器の 変化に追従するように不均一分布の改善および都市部 への集中傾向がみられた。

このように 1999 年と 2014 年を比較すると, 二次医 療圈間での人口あたりの放射線診療資源の偏在は小さ くなったが，人口の都市部への集中が要因となり，放 射線診療資源も都市部に集中する傾向にあることが明 らかになった。このことは，札幌や旭川などの都市部 を含む医療圈では放射線診療資源が過密化しており， その一方で, 他の医療圈では放射線診療資源の密度が 低くなっていることを示すものである，北海道の二次 医療圈の面積は広大であり, 他県の県全体の面積より も広いところもあるため, 過疎化が進む医療圈におけ る放射線診療資源への地理的なアクセシビリティの低 下が危惧される，過疎化が進む医療圈においても，一 定の医療提供体制を継続的に維持するだけの放射線診 療資源が必要であるが, 医療機関の経営者側から見れ ば新たな設備投資は容易ではなく，医療機関等の設備
投資に関する調査によると, 投資総額における画像診 断システムへの投資額は病院で約 3 割, 一般診療所で 約 5 割を占めていると報告されている ${ }^{24)}$. フランスで は医療需要を最適な形で充足するために, 医療供給の 必要な変化を予測し実現することを目的とした地域圈 保健医療組織計画によって医療活動や高額医療機器の 量的な目標が示されている25). 今後, 日本でも放射線 診療資源の計画的配置が必要になるかもしれず，その 場合には人口分布と放射線診療資源の分布状況を定量 的に反映することが可能な GC および HHI の併用手 法は有用な評価指標になり得ると考える.

本研究の限界として, 医療の公平性の評価指標は, 人口あたりの医療資源数が等しいことに限るものでは なく，その均一な分布が必ずしも医療の公平性を満た す状態でもない点があげられる，国民皆保険制度での 医療サービスの提供には一定の公平性が必要であるも のの, 限られた診療資源を効率的に利用することも重 要であるため, 医療機関へのアクセスのし易さや施設 間の連携なども含めた効率性の視点からの検討も必要 である. 次に, 本研究では GC および $\mathrm{HHI}$ を相対的 に比較して評価したが, その偏在の状態が患者の予後 や医療従事者の労働環境にどのような直接的な影響を 及ぼしているのかは明らかになっていない。また，放 射線診療資源の対象として放射線診療機器, 技師扔よ び医師に限定した点があげられる。埼玉県における CT 装置の稼働実態についての調査検討によると, 63\%の施設において画像診断専門医が不在であったと 報告されており ${ }^{26)}$, 放射線治療に関する資源の分布に 関する研究では, 放射線腫瘍医および放射線治療専門 放射線技師の地理的分布について三次医療圈単位での 格差は 2005 年から 2007 年にかけて縮小しているが, 日本の $26 \%$ 二次医療圈では放射線治療を提供でき ないことが指摘されている ${ }^{13)}$.今後は, 対象を放射線 診断や放射線治療を専門とする放射線科医まで広げて 検討する必要があると考える。これらを踏まえた上 で，医療政策立案に対してょり有用な資料を提供する ためには, 医療圈ごとの人口変動および患者動向を加 味した放射線診療資源の適正配置のシミュレーション が今後必要になると考えられる。

\section{4. 結 語}

本研究では 1999 年から 2014 年における北海道の放 射線診療資源について，GC と HHI を併用してその偏 在および分布の経年変化を評価した. 医師の分布と比 較してCT, MRI, 技師は均一に分布しており, 特に CT は最も均一な分布であったが, 反面 RTF は不均 
一な分布であった。 また, CT 以外の放射線診療資源 は人口分布と比較して集中度が高く, 地方よりも都市 部に集中して分布していた. 1999 年から 2014 年にお いて，放射線診療資源は GC が低下し HHI が上昇し
ており，都市部を中心に配置されたが，不均一分布は 改善していたＧC と HHI の併用は医療資源偏在の 詳細な評価につながり，医療資源の計画配置の際に有 用な指標となり得ることが示唆された。

\section{参考文献}

1) OECD. Health at a glance 2013. http://www.oecd-ilibrary.org/ (Accessed 2016.1.27).

2）厚生労働省. 平成 21 年度第 2 回へき地保健医療対策検討 会資料. http://www.mhlw.go.jp/stf/shingi/other-isei.html?tid $=127246$ (Accessed 2016.1.27).

3）今中雄一、ヘルスサービスリサーチ(5)「医療の質, コス 卜，アクセス，そして満足度：医療制度づくりと HSR」. 日本公衛誌 2010; 57(11): 1023-1028.

4) 山口 建, 堀内智子. がん診療連携拠点病院の現状と課 題. J. Natl. Inst. Public Health 2008; 57(4): 318-326.

5) 北海道. 北海道医療計画. 札幌: 北海道保健福祉部保健 医療局医療政策課，2008.

6）北海道. 北海道医療計画〔改訂版〕. 札幌: 北海道保健福 祉部医療政策局医療薬務課, 2013.

7）遠藤久夫. 我が国の医療提供システムと準市場一ネット ワーク原理に基づく医療提供システム. 季刊・社会保障 研究 2008; 44(1): 19-29.

8) Kobayashi Y, Takaki H. Geographic distribution of physicians in Japan. Lancet 1992; 340(8832): 1391-1393.

9) Toyabe S. Trend in geographic distribution of physicians in Japan. Int J Equity Health 2009; 8: 5.

10) Matsumoto $M$, Inoue $K$, Farmer J, et al. Geographic distribution of primary care physicians in Japan and Britain. Health Place 2010; 16(1): 164-166.

11) Ogasawara $K$, Nambu $T$, Sakurai $T$. Radiological equipment and staffs distribution in Hokkaido, Japan: Lorenz curve and locational Gini index analyses. Jpn J Health Economics and Policy 2004; 14: 17-26.

12) Ohba $H$, Narumi $M$, Hosokawa $Y$, et al. Measuring the inequalities in radiotherapy health resources in Japan: comparison of the Hokkaido-Tohoku and Tokyo districts. Jpn J Radiol 2010; 28(1): 20-26.

13) Tanikawa $T$, Ohba H, Ogasawara K, et al. Geographical distribution of radiotherapy resources in Japan: investigating the inequitable distribution of human resources by using the Gini coefficient. J Radiat Res 2012; 53(3): 489-491.

14）小松憲一, 岡山雅信, 松嶋 大, 他. ジニ係数・ハーフィ ンダール・ハーシュマン指数を用いた DPC データの解析
一平準度が高く，幅広い自治医科大学付属病院総合診療 部の入院患者一，プライマリ・ケア 2009; 32(3): 142-148.

15）厚生労働省. 医療施設調査. https://www.e-stat.go.jp/SG1/ estat/GL08020101.do?_toGL08020101_\&tstatCode $=00000$ 1030908\&requestSender=dsearch (Accessed 2016.1.27).

16）厚生労働省. 病院報告. https://www.e-stat.go.jp/SG1/estat/ GL08020101.do? toGL08020101 \& \&statCode $=000001030749$ \&requestSender $=$ dsearch (Accessed 2016.1.27).

17) Ameryoun A, Meskarpour-Amiri M, Dezfuli-Nejad ML, et al. The assessment of inequality on geographical distribution of Non-cardiac intensive care beds in Iran. Iranian J Public Health 2011; 40: 25-33.

18）公正取引委員会. 用語の解説. http://www.jftc.go.jp/soshi ki/kyotsukoukai/ruiseki/yougo.html (Accessed 2016.1.27).

19）公正取引委員会. 企業結合審査に関する独占禁止法の運 用指針. http://www.jftc.go.jp/dk/kiketsu/guideline/guideline/ kaisei/index.html (Accessed 2016.1.27).

20) Tanihara $S$, Kobayashi $Y$, Une $H$, et al. Urbanization and physician maldistribution: a longitudinal study in Japan. BMC Health Serv Res 2011; 11: 260.

21) Sasaki H, Otsubo $T$, Imanaka $Y$. Widening disparity in the geographic distribution of pediatricians in Japan. Hum Resour Health 2013; 11: 59.

22) 北海道. 北海道地域医療再生計画 (平成 24 年度補正予 算). http://www.mhlw.go.jp/bunya/iryou/saiseikikin/d1/h24 hokkaido-keikaku.pdf (Accessed 2016.1.27).

23）吉田あつし, 幸野 聡。茨城県における診療所間の空間 的競争. 日本統計学会誌 2007; 37(1): 133-150.

24）中央社会保険医療協議会. 医療機関等の設備投資に関す る調査結果報告書. http://www.mhlw.go.jp/file/05-Shingi kai-12404000-Hokenkyoku-Iryouka/0000024030.pdf (Accessed 2016.1.27).

25）松本由美. フランスに扔ける保健医療計画の導入と展開 一医療への平等なアクセスの実現を目指して一。海外社 会保障研究 2012; 178: 81-91.

26）小川 清. 埼玉県内における CT 装置の稼働実態とその 運用に関する研究. 日本診療放射線技師会誌 2013; 60 (730): 32-37. 